\title{
KEARIFAN LOKAL PADA KABANTI MASYARAKAT BUTON DAN RELEVANSINYA DENGAN PENDIDIKAN KARAKTER
}

\author{
Sahlan \\ FKIP Universitas Haluoleo, Kendari, Sulawesi Tenggara \\ Kampus Bumi Tridharma Anduonohu, Telp. (0401) 3190067/ 081341586699 \\ email: alansahlan17@gmail.com
}

\begin{abstract}
This article aimed to describe a local wisdom in kabanti of Buton's people, like (a) local wisdom value of kabanti in term of religion, (b) local wisdom value of kabanti in term of norm, (c) local wisdom value of kabanti in term of social aspect, and (d) local wisdom value of kabanti in term of characteristical education. Data resource of this research were taken from three kabanti's texts which were arranged by Haji Abdulu Ganiyyu, Ajonga Inda Malusa, Kulipopo Mainawa, and Payasa Mainawa. To analyse the validity of data, this research aplied triangular technique, such as teoritical trianggular, logical triangular, and expert triangular. Data analysing methode were resoluted by hermeneutical anlysis and semiotical analysis. This research found that kabanti of Buton's people had a contents of local wisdom values which were used and applied by society hereditary. Kabanti reflected a local wisdom values in four aspects. first, religious aspect of Buton's people where very closed to Islam doctrin. It coul be shown at the social activity, in term of people relation with The Creator, people relation with people, and people relation with universe. Second, norm aspect of Buton's people had a punctual values to the rules, equitable in the legal supremacy, and self care. Third, social aspect of Buton's people had a glorious value, love, care, respect, tolerance to differenciation. Fourth, local wisdom values of kabanti Buton's people relevanced to the pillars of characteristical education, then implemented by the teacher in learning a character.
\end{abstract}

Penelitian ini bertujuan untuk mengungkap kearifan lokal pada kabanti masyarakat Buton, yaitu (a) mengungkap nilai-nilai kearifan lokal dalam kabanti 
pada aspek religius, (b) mengungkap nilai-nilai kearifan lokal dalam kabanti pada aspek norma, (c) mengungkap nilai-nilai kearifan lokal dalam kabanti pada aspek sosial, dan (d) mengungkap relevansi nilai-nilai kearifan lokal dalam kabanti dengan pilar-pilar pendidikan karakter. Untuk mendeskripsikan tujuan itu penelitian menggunakan metode analisis isi (content analysis). Sumber data penelitian berasal dari tiga naskah kabanti yang dikarang oleh Haji Abdulu Ganiyyu, Ajonga Inda Malusa, Kulipopo Mainawa, dan Payasa Mainawa. Analisis keabsahan data menggunakan teknik triangulasi, yakni triangulasi teoritis, triangulasi logis, dan triangulasi pakar. Metode analisis data dipadukan dengan analisis hermeneutik dan analisis semiotik. Temuan penelitian menyimpulkan bahwa kabanti masyarakat Buton memiliki kandungan nilai-nilai kearifan lokal yang digunakan dan diterapkan oleh masyarakat secara turun-temurun. Dalam kabanti tercermin nilai-nilai kearifan lokal pada empat aspek. Pertama, aspek religius masyarakat Buton sangat kental dengan ajaran Islam. Hal ini tampak pada aktivitas masyarakat, baik dalam hubungan manusia dengan pencipta, hubungan manusia dengan manusia, dan hubungan manusia dengan alam. Kedua, aspek norma masyarakat Buton memiliki kedisiplinan pada aturan, adil pada penerapan hukum, dan bermawas diri. Ketiga, pada aspek sosial masyarakat Buton memiliki nilai-nilai luhur, kasih sayang, saling peduli, saling menghormati, toleransi pada keberagaman, dan saling menghargai. Keempat, nilai-nilai kearifan lokal pada kabanti masyarakat Buton relevan dengan pilarpilar pendidikan karakter, sehingga dapat diimplementasikan oleh guru pada pembelajaran karakter.

Key words: local wisdom, character, norm, value, social

\section{Pendahuluan}

Sastra daerah dalam bentuk puisi seperti kabanti masyarakat Buton, banyak mengandung nilai-nilai ajaran tentang kehidupan. Sebagai karya kreatif puisi menggunakan bahasa simbol, sehingga untuk memahaminya memerlukan penelitian ilmiah. Penelitian ilmiah tentang kabanti pada masyakat Buton dimaksudkan untuk menggali berbagai informasi tentang nilai-nilai kehidupan masyarakat Buton pada masa lalu. Tujuannya agar dapat menopang nilai-nilai kehidupan masa kini yang biasa disebut dengan nilai-nilai kearifan lokal. Kabanti dikenal oleh masyarakat Buton sejak awal kesultanan pada abad XV, sehingga karya sastra ini dipandang sebagai bentuk sastra yang paling tua dalam masyarakat Buton. Penulisan kabanti mulai populer pada pemerintahan Sultan Muhammad Idrus Kaimuddin (1824-1851) karena Sultan sendiri banyak menulis kabanti yang bernafaskan Islam.

Kabanti sebagai salah satu bentuk sastra daerah perlu dipelihara dan di kembangkan. Jika tidak dipelihara dengan baik maka dikhawatirkan mengalami 
proses kepunahan akibat gesekan budaya asing. Langkah yang perlu dilakukan adalah pengkajian kabanti secara ilmiah agar dapat menemukan nilai-nilai luhur pada masyarakat Buton. Telaah nilai-nilai kearifan lokal pada kabanti sangat relevan dengan upaya pengembangan keilmuan, sehingga temuan pada penelitian ini dapat dikolaborasikan dengan pendidikan untuk melahirkan local genius dan nilai-nilai karakter bangsa. Apalagi, kajian sebelumnya (Taalami, 2008) banyak mengandung nilai-nilai luhur kehidupan. Sebagian besar kabanti sarat dengan nilai-nilai kehidupan seperti bait kabanti Ana-ana Maelu 'anak yatim piatu' berikut ini:

Boli osea rampaa kalakiamu

Pekalapea incamu momatambena

Motuapa tapekatambe karota

Inda malingu mia momalangana

Jangan ikuti karena kebangsawananmu

Perbaiki hatimu yang selalu merendah

Walaupun kita selalu merendahkan diri

Tidak akan lupa orang yang tinggi (di atas)

Berbicara tentang kearifan lokal (local wisdom) tidak dapat dipisahkan dengan nilai-nilai luhur bangsa. Kearifan lokal merupakan pengetahuan yang digunakan oleh masyarakat lokal untuk bertahan hidup secara turuntemurun. Kearifan lokal merupakan hasil dari kecerdasan suatu masyarakat lalu digunakan oleh sesamanya sebagai sarana pencerdasan. Memahami dan mengimplementasikan kearifan lokal sejak dini dapat menjadi landasan kehidupan masyarakat, terutama untuk menangkal pengaruh budaya asing yang saat ini banyak menimpa generasi muda. Pada konteks ini nilai-nilai kehidupan masyarakat lokal yang tercermin dalam sastra dan budaya lokal dapat menopang nilai-nilai luhur bangsa (Rahyono, 2009: 7).

Berdasarkan uraian-uraian tersebut, maka yang menjadi tujuan penelitian ini adalah untuk mengungkap nilai-nilai kearifan lokal pada kabanti masyarakat Buton sebagai landasan pendidikan karakter. Secara rinci tujuan yang ingin dicapai adalah (1) mengungkap nilai-nilai kearifan lokal dalam kabanti pada aspek religius, (2) mengungkap nilai-nilai kearifan lokal dalam kabanti pada aspek norma, (3) mengungkap nilai-nilai kearifan lokal dalam kabanti pada aspek sosial, dan (4) mengungkap relevansi nilai-nilai kearifan lokal dalam kabanti dengan pilar-pilar pendidikan karakter. 


\section{Teori Kearifan Lokal}

Istilah kearifan lokal (local wisdom) terdiri dari dua kata, yaitu kearifan yang berarti kebijaksanaan dan lokal yang berarti suatu tempat. Secara umum kearifan lokal (local wisdom) dapat diartikan sebagai gagasan setempat yang bersifat bijaksana, penuh kearifan, bernilai baik dan terpelihara oleh masyarakat setempat (Taalami, 2010: 26). Jika ditelaah secara linguistic, kata kearifan dibentuk dari akar kata 'arif yang bermakna 'bijaksana', cerdik-pandai'. Jadi istilah kearifan berarti, (1) kebijaksanaan atau (2) kecerdasan, sehingga kata kearifan berkenaan dengan dua hal, yaitu (a) karakter atau kepribadian, dan (b) kecerdasan atau kognisi. Batasan ini yang menjadi kerangka acuan pembahasan kearifan lokal masyarakat.

Beberapa ahli berpendapat untuk memadukan kearifan lokal (local wisdom) dengan konsep budaya lokal (local genius) yakni kecerdasan yang dimiliki oleh sekelompok masyarakat untuk digunakan sebagai pencerdasan pula (Rahyono, 2009: 4). Sementara itu, kearifan lokal merupakan suatu hasil adaptasi dari suatu komunitas yang berasal dari generasi ke generasi berikutnya (Gunawan, 2003: 6).

Hal itu sejalan dengan pendapat yang menegaskan bahwa kearifan lokal dipandang sebagai suatu adaptasi tentang pengalaman hidup masyarakat yang telah diterapkan secara turun-temurun sehingga menjadi suatu tradisi masyarakat yang bersangkutan (Sztompka, 2008: 63).

Berdasarkan pandangan-pandangan di atas dapat disimpulkan bahwa kearifan lokal merupakan suatu pengetahuan lokal yang digunakan oleh suatu komunitas masyarakat lokal sehingga mereka dapat bertahan hidup dalam suatu lingkungan kolektif. Pada konteks ini, kearifan lokal dapat menyatu dengan sistem; kepercayaan, pandangan hidup, norma, nilai sosial (etika), pengetahuan, dan budaya yang diekspresikan dalam penerapan tradisi yang dianut oleh masyarakat secara turun-temurun. Implikasi teori-teori tersebut terhadap penelitian ini adalah kearifan lokal dipandang sebagai tradisi masyarakat yang terungkap pada kabanti masyarakat Buton dengan cerminan nilai-nilai luhur kehidupan. Tradisi dan budaya yang dikaji merupakan bentuk kearifan lokal masyarakat yang telah diterapkan secara turun-temurun.

Kendati pun terdapat formulasi yang berbeda antar ahli, secara esensial 'kearifan lokal' merupakan sistem budaya lokal yang meliputi aspek (1) nilai, (2) norma, (3) perilaku, (4) kebudayaan, (5) pengetahuan, (6) keyakinan, dan (7) pandangan hidup. Implementasinya dalam penelitian ini ditekankan pada empat hal yaitu (a) aspek religius, (b) aspek norma, (c) aspek sosial, dan (d) 
aspek pendidikan. Keempat aspek tersebut menjadi tujuan pembahasan yang dikaitkan dengan pembelajaran karakter yang sekarang ini menjadi perhatian dalam pengembangan kurikulum atau pembelajaran di sekolah. Maka guru mestinya memiliki kreativitas dan inovatif dalam pembelajaran yang berbasis pada nilai-nilai kearifan lokal masyarakat.

\section{Konsepsi Kabanti Masyarakat Buton}

Kabanti merupakan salah satu jenis kesusastraan Buton berbentuk puisi. Kesusastraan jenis ini telah dikenal oleh masyarakat Buton sejak masa Kerajaan Buton. Oleh karena itu, kesusastraan jenis kabanti merupakan kesusastraan masyarakat Buton yang paling tua. Kabanti berkembang pesat setelah masuknya agama Islam di Kerajaan Buton. Masuknya ajaran agama Islam sanggup mengubah dan mewarnai perkembangan sastra masyarakat Buton. Petuah-petuah tentang nilai-nilai dan falsafah hidup disampaikan melalui kabanti, yang pada prinsipnya merupakan hasil pengolahan secara bebas dari kesusastraan bentuk prosa. Sejak zaman itu, kabanti tidak saja berkembang secara lisan, tetapi juga berkembang secara tulisan.

Dari segi bentuknya, kesusastraan jenis kabanti dapat dikelompokkan menjadi dua bagian, yaitu pantun dan syair. Kabanti yang tergolong kelompok pantun pada umumnya bentuknya pendek-pendek, kadang-kadang terdiri atas sampiran dan isi, dan kadang-kadang pula hanya berupa isi saja. Syair bentuknya panjang-panjang, dan merupakan hasil pengolahan secara bebas dari kesusastraan bentuk prosa. Biasanya terdiri atas 8 sampai 12 suku kata, antaranya memakai 4 tekanan, biasanya terdiri atas 3 sampai 4 perkataan (Niampe, 2000: 2), sehingga kabanti merupakan karya sastra bentuk puisi.

Puisi sebagai salah satu bentuk karya sastra tidak hanya sebagai sistem norma, melainkan terdiri dari beberapa lapis norma yang menuangkan pengalaman universal dan pengalaman individu melalui ungkapan bahasa. Beberapa pandangan ahli tentang puisi yaitu

1. Carlyle mengemukakan bahwa puisi merupakan pemikiran yang bersifat musikal, karena pencipta puisi memikirkan rangkaian bunyi yang merdu disusun dengan menonjolkan bunyi yang merdu.

2. Wordsworth mengemukakan bahwa puisi merupakan pernyataan perasaan seseorang pengarang yang bersifat imajinatif.

3. Dunton berpendapat bahwa puisi itu merupakan pemikiran manusia secara konkret dan artistik melalui bahasa emosional dan berirama (Pradopo, 2000: 14). 
Dari ketiga pendapat di atas dapat disimpulkan bahwa karakteristik puisi ialah (1) pemikiran yakni meliputi ide dan emosi, (2) bentuk, yakni meliputi rima dan irama, serta (3) kesan yakni meliputi imajinasi dan pesan. Sebagai implikasi teori pada penelitian ini adalah menekan pada unsur pemikiran (ide) dan kesan (makna) yang terdapat dalam Kabanti puisi masyarakat Buton.

\section{Pendidikan Karakter}

Pendidikan merupakan upaya terencana dalam mengembangkan potensi peserta didik, sehingga mereka memiliki sistem berpikir, nilai, moral, dan keyakinan yang diwariskan oleh masyarakatnya dan mengembangkan warisan tersebut ke arah kehidupan masa kini dan masa mendatang. Sementara itu, istilah karakter adalah watak, tabiat, akhlak, atau kepribadian seseorang yang terbentuk dari hasil internalisasi berbagai kebajikan (virtues) yang diyakini dan digunakan sebagai landasan untuk cara pandang, berpikir, bersikap, dan bertindak. Kebajikan terdiri atas sejumlah nilai, moral, dan norma, seperti jujur, berani bertindak, dapat dipercaya, dan hormat kepada orang lain. Interaksi seseorang dengan orang lain menumbuhkan karakter masyarakat dan karakter bangsa. Pengembangan karakter bangsa hanya dapat dilakukan melalui pengembangan karakter individu seseorang yang hanya dapat dilakukan dalam lingkungan sosial dan budaya yang bersangkutan. Dengan demikian, pendidikan karakter individu yang berlandas pada kearifan lokal dapat menopang pendidikan karakter bangsa untuk mewujudkan generasi yang berkepribadian dan bermartabat.

Berdasarkan pengertian budaya, karakter bangsa, dan pendidikan yang telah dikemukakan di atas maka pendidikan budaya dan karakter bangsa dimaknai sebagai pendidikan yang mengembangkan nilai-nilai budaya dan karakter bangsa pada diri peserta didik sehingga mereka memiliki nilai dan karakter sebagai karakter dirinya, menerapkan nilai-nilai tersebut dalam kehidupan sebagai anggota masyarakat, dan warga negara yang religius, nasionalis, produktif dan kreatif. Atas dasar pemikiran itu, pengembangan pendidikan budaya dan karakter sangat strategis bagi keberlangsungan dan keunggulan bangsa di masa mendatang.

\section{Metode dan Prosedur Penelitian}

Penelitian ini merupakan bentuk penelitian yang menggunakan analisis isi (content analysis), sehingga pelaksanaannya mengacu pada prosedur analisis isi. Oleh karena itu peneliti mengembangkan tiga langkah (prosedur) Pertama, pengadaan data yaitu (a) penentuan unit analisis melalui pembacaan secara 
cermat dan berulang, (b) penentuan sampel data jika data yang diteliti cukup kompleks sesuai dengan tema yang ada, (c) perekaman dan pencatatan data menjadi masalah pokok karena analisis konten berupa data simbolik yang tidak berstruktur. Kedua, validasi data yakni menggunakan pola validasi semantis yakni mengukur tingkat kesensitifan makna simbolik yang berkaitan dengan konteks. Pengukuran makna simbolik dikaitkan dengan konteks karya sastra dan konsep analisis. Ketiga, proses inferensi dan analisis sebagai salah satu prosedur analisis konten. Inferensi dimaksudkan untuk menarik simpulan yang bersifat abstrak. Selanjutnya melakukan penyajian dan pembahasan data.

Data penelitian ini meliputi dua bentuk data yaitu berupa kearifan lokal dalam kabanti dan kearifan lokal pada masyarakat Buton. Data pertama dari tiga naskah karya Haji Abdulu Ganiyyu: (a) Paiyasa Mainawa, (b) Kulipopo Mainawa, dan (c) Ajonga Inda Malusa. Data kedua diambil pada pengamatan dan wawancara tentang religius masyarakat, norma masyarakat, kehidupan sosial sebagai masyarakat multikultur, dan implikasi nilai kearifan lokal dalam pendidikan karakter di sekolah. Berdasarkan karakteristik data, maka sumber data terbagi menjadi dua yaitu (a) sumber data yang berupa dokumentasi yakni naskah kabanti dan (b) sumber data pengamatan atau wawancara untuk mendapatkan suasana kehidupan masyarakat Buton.

Analisis keabsahan data digunakan teknik triangulasi. Ada dua bentuk triangulasi untuk kroscek data yaitu triangulasi teoretis yakni melihat serta mengkonfirmasikan hasil analisis data dengan beberapa teori yang ada dan triangulasi logis yakni mengkonfirmasikan hasil analisis data dengan ahli atau pembimbing. Di samping bentuk triangulasi tersebut dalam penelitian ini digunakan pula dua teknik triangulasi, yaitu triangulasi pakar dan triangulasi kolegial. Triangulasi pakar adalah melakukan wawancara dengan ahli bidang telaah kabanti sebagai kearifan lokal, triangulasi kolegial ialah melakukan diskusi dengan teman-teman sejawat untuk memberikan pendapat.

Analisis data dilakukan melalui empat langkah sesuai dengan metode analisis isi. Pertama, peneliti melakukan pendataan teks yang menjadi bahanbahan analisis yakni mengidentifikasi teks-teks yang mengandung nilai-nilai kearifan lokal. Kedua, teks yang telah diklasifikasi berdasarkan unit-unit, lalu dilakukan suatu pendalaman melalui pengamatan dan wawancara. Ketiga, melakukan analisis komponen sebagai pendalaman temuan yang telah diidentifikasi pada catatan lapangan untuk membuat inferensi dan simpulan. Keempat, peneliti melakukan pemadatan kata-kata yang simbolik yang telah diidentifikasi dalam unit-unit inferensi, lalu melakukan analisis tema untuk 
membuat pemahaman yang komprehensif tentang butir-butir yang menjadi fokus atau masalah penelitian yang telah dirancang (Glasser, 1986: 102).

\section{Pembahasan}

Analisis data dari tiga naskah kabanti disimpulkan terkandung nilainilai kearifan lokal masyarakat Buton. Agar pembahasan hasil temuan terurai secara sistematis, maka susunan sajian pembahasan dibagi menjadi (a) nilainilai kearifan lokal dalam kabanti pada aspek religius, (b) nilai-nilai kearifan lokal dalam kabanti pada aspek norma, (c) nilai-nilai kearifan lokal dalam kabanti pada aspek sosial, dan (d) relevansi nilai-nilai kearifan lokal dalam kabanti serta implikasinya terhadap pendidikan karakter.

\section{Nilai-nilai Kearifan Lokal dalam Kabanti pada Aspek Relegius}

Nilai-nilai kearifan lokal aspek religius pada kabanti masyarakat Buton tergambar pada kabanti PM bait 55-57 dan kabanti KM bait 33-34, tentang hubungan manusia dengan Tuhan. Pada kabanti AIM banyak membahas tentang hubungan antarmanusia dan hubungan manusia dengan alam seperti tampak pada bait; 225-227, 248-249, 338-339 dan 1026-1027.

Masyarakat Buton dalam masalah ketuhanan menunjukkan adanya keterkaitan ajaran tasawuf dengan bentuk kearifan lokal yang terdapat pada kabanti PM (bait 55-57). Dalam hasil analisis data disimpulkan bahwa konsepsi tentang Tuhan harus ditelusuri melalui eksistensi diri kita sebagai ciptaan Tuhan. Untuk mengenal Tuhan dalam konsepsi masyarakat Buton harus mengenal diri kita. Hal ini sesuai dengan Hadis Rasululah SAW yang artinya' Orang bertanya kepada Rasulullah SAW, "Wahai Rasulullah di mana Allah, di bumi atau di langit?", Rasulullah menjawab "Di dalam hati (kalbi) hambanya yang beriman" (HR. Ibnu Umar RA).

Berdasarkan temuan penelitian tersebut di atas, menunjukkan bahwa masyarakat Buton mempelajari masalah ketuhanan sebagai konsepsi dalam kehidupan bermasyarakat. Masyarakat yang selalu menyadari eksistensi diri sebagai hamba Allah, akan selalu mengarahkan kepada sifat-sifat merendah, selalu bersyukur, dan bertawakal kepada Maha Pencipta. Artinya, kehidupan bermasyarakat dibalut dengan nilai-nilai keimanan kepada Allah dengan kesadaran sebagai hamba. Olehnya itu, dalam tatanan kehidupan masyarakat Buton berjalan pada nilai-nilai ke-Islaman serta norma-norma adat.

Pada temuan lain dalam kabanti PM (bait 35-34) dijelaskan bahwa inti kemanusiaan adalah keimanan kepada Allah SWT. Tidak bermakna seorang 
yang menyatakan diri sebagai pemeluk agama Islam manakala tidak mengerti tentang Tuhannya. Oleh karena itu, kandungan kabanti pada bait ini ditegaskan pembentukan keimanan (tauhid) pada masyarakat dilakukan oleh pemerintah melalui utusan kesultanan dan para ulama. Artinya, pembentukan pandangan hidup masyarakat tentang Tuhan menjadi tanggung jawab pemerintah. Maka seorang sultan bagi masyarakat Buton mendapat gelar Khalifah Alhamsi yaitu memiliki sifat saleh, suci batinnya, menjadi panutan, dan berilmu tauhid.

Itulah sebabnya, penanaman nilai-nilai ketuhanan dalam masyarakat Buton dilakukan secara terorganisir, yaitu mulai sultan sampai kemasyarakat biasa. Pusat pemerintahan membentuk badan yang dinamakan Sarano Agama yang memegang urusan agama yang berhubungan dengan Islam. Dewan tersebut berkedudukan di Mesjid Agung Keraton Buton. Badan tersebut menjalin kerja sama yang erat dengan pusat kekuasaan sultan dan Sarana Wolio (lembaga adat). Dengan demikian ketiga lembaga tersebut (Sarana Agama, pemerintahan, dan Sarana Wolio) dijalankan secara terpadu, sehingga ajaran Islam menyebar dan mengental di hati masyarakat Buton. Hal ini sesuai dengan motto, 'Adat bersendikan sara dan sara bersendikan kitabullah. Keseluruhan perilaku serta pengetahuan yang telah terpendam dalam hati masyarakat menjadi pandangan hidup yang pada akhirnya menjadi kearifan lokal dalam masyarakat Buton.

Sifat-sifat itulah yang dimaksudkan oleh informan sebagai masyarakat Buton yang madani yakni sifat bawaan yang tidak pernah luntur di manapun ia berada. Oleh karena itu, bagi masyarakat Buton selalu menempatkan syariat Islam di atas segala-galanya. Hal tersebut dapat terlihat pada semboyan falsafah Buton, "Bolimo karo sumanamo lipu, bolimo lipu sumanamo sara, bolimo sara sumanamo agama" yang maknanya, "Tidak perlu diri asalkan negeri tetap utuh, tidak perlu negeri asalkan hukum tegak, tidak perlu hukum asalkan agama dilaksanakan". Semboyan masyarakat Buton tersebut dapat berimplikasi pada pandangan atau falsafah hidup masyarakat.

Falsafah hidup masyarakat Buton berlandas pada masalah pokok yaitu; pandangan hidup tentang hubungan manusia dengan Maha Pencipta (Allah), pandangan hidup tentang hubungan manusia dengan manusia lain, dan pandangan hidup tentang hubungan manusia dengan alam (wilayah kehidupan). Pandangan hidup masyarakat Buton tentang hubungan manusia dengan pencipta, maka manusia harus memandang dirinya sebagai mahluk yang lemah. Oleh karena itu pengabdian kepada Allah menjadi landasan kehidupan yang tidak dapat dihindari. Hasil analisis kabanti disimpulkan bahwa konsepsi tentang 
Allah harus ditelusuri melalui eksistensi diri kita sebagai ciptaan-Nya. Untuk dapat mengenal Allah dalam pandangan masyarakat Buton harus lebih awal mengenal keberadaan dirinya sebagaimana tertuang dalam ajaran tasawuf yang banyak dipelajari masyarakat Buton. Itulah sebabnya setiap produk budaya pada masyarakat Buton bersandar pada nilai-nilai Islam.

\section{Nilai-nilai Kearifan Lokal dalam Kabanti pada Aspek Norma}

Norma merupakan suatu acuan atau pedoman tingkah laku yang patut dan tidak patut dilakukan oleh anggota masyarakat. Dengan kata lain, norma dapat dimaknai sebagai tolok ukur yang menjadi acuan benar salahnya suatu perilaku masyarakat. Norma dalam kehidupan masyarakat selalu berkaitan erat dengan nilai-nilai kehidupan (kearifan lokal) suatu masyarakat. Nilainilai luhur kehidupan masyarakat banyak tercermin dalam produk budaya termasuk pada kabanti. Implementasi norma dan nilai-nilai luhur kehidupan masyarakat Buton yang terkandung dalam kabanti dapat terefleksi melalui kehidupan masyarakat.

Nilai-nilai kearifan lokal dalam kabanti pada aspek norma berlandaskan syariat Islam sebagai sumber utama. Hal ini tergambar pada kabanti PM bait 77-78. Penerapan norma terjabar pada tiga pilar norma, yaitu norma hukum, norma sosial, dan norma adat. Ketiga bentuk norma tersebut memiliki peranan penting dalam tata kehidupan masyarakat, karena dapat menjadi standar atau acuan untuk berprilaku, bersikap, serta berpikir. Norma hukum yang tertuang dalam kabanti AIM 821-823 dan 982-984 menjadi acuan dalam penerapan hukum negara yang disebut dengan hukum atau sara. Norma sosial yang tampak pada kabanti PM bait 74-75 kabanti AIM bait 42-44, 129-131 menjadi acuan dalam berperilaku dan tata krama. Norma adat sebagaimana tergambar pada kabanti AIM 270-271, 940-941 menjadi acuan penerapan budaya atau adat-istiadat dalam masyarakat Buton. Hal ini dilakukan melalui satu lembaga kesultanan yang disebut Kenepulu Bula di bawah sultan.

Berdasarkan analisis data disimpulkan bahwa nilai-nilai kearifan lokal masyarakat pada aspek norma tercakup pada tiga pilar norma yaitu; norma hukum, norma sosial, dan norma adat-istiadat. Masing-masing norma tersebut memiliki peranan penting dalam tata kehidupan masyarakat, karena dapat menjadi pedoman bersikap dan berperilaku. Norma-norma hukum, sosial, dan adat-istiadat menjadi acuan masyarakat Buton dalam memberikan sanksi atau hukum. Pada aspek norma hukum menjadi acuan penerapan hukum, norma sosial menjadi acuan memberikan sanksi sosial terhadap pelanggaran 
susila, dan aspek norma adat-istiadat menjadi acuan penerapan sanksi terhadap pelanggaran adat masyarakat Buton. Penerapan sanksi terhadap pelanggaran norma tidak pandang bulu dalam arti telah diterapkan pada siapa saja, baik pejabat maupun masyarakat biasa.

\section{Nilai-nilai Kearifan Lokal dalam Kabanti pada Aspek Sosial}

Nilai-nilai kearifan lokal masyarakat pada aspek sosial mengandung nilainilai luhur yang sarat dengan nuansa keislaman. Artinya, jabaran di dalamnya mencakup budi pekerti atau akhlakul karimah yang dalam kabanti diberikan istilah budimani. Hal ini tergambar pada sebagaian besar kabanti PM bait 138139, dan kabanti AIM bait 134-136, 201-207, 226-227, 835-837. Pada bait-bait ini menguraikan tentang budi pekerti (budimani) yang mempunyai beberapa indikator yang merujuk pada falsafah Buton 'bhinci-bhinciki kuli'. Falsafah tersebut tertuang dalam empat prinsip hidup yaitu, (a) sesama rmanusia harus selalu saling menghormati, (b) sesama manusia harus selalu saling peduli, (c) sesama manusia harus selalu saling menyayangi, (d) sesama manusia harus selalu saling memuliakan. Orang yang memiliki perilaku tersebut masyarakat menjuluki budimani (berakhlak mulia).

Nilai-nilai kearifan lokal dalam kabanti pada aspek sosial terkandung nilai-nilai luhur masyarakat Buton yang sarat dengan nuansa Islam. Hal ini tercakup dalam falsafah Buton 'bhinci-bhinciki kuli'. yang biasa dikenal dengan istilah sara pataanguna 'hukum yang empat'. Sara pataanguna merupakan hukum adat masyarakat Buton yang memberikan inspirasi kepada masyarakat untuk menjalin hubungan sesama manusia secara harmonis. Kandungan dari falsafah tersebut bertujuan untuk dapat memilah-milah antara kebaikan dan keburukan dalam berperilaku yang dikenal dengan budi pekerti.

Berdasarkan hasil analisis menunjukkan nilai-nilai kearifan lokal yang terkandung dalam kabanti sarat dengan nilai-nilai luhur kehidupan. Jabaran di dalamnya mencakup akhlakul karimah yang dalam kabanti diberikan istilah budimani. Pada konteks ini budimani mempunyai indikator yang merujuk pada falsafah 'bhinci-bhinciki kuli' yang memuat prinsip hidup; (a) pomaa-maasiaka, 'sesama manusia harus selalu saling menyayangi', (b) pomae-maeka, 'sesama manusia harus selalu saling menghormati', (c) popia-piara, 'sesama manusia harus selalu saling melindungi', dan (d) poangka-angkataka, 'sesama manusia harus selalu saling memuliakan'. Orang yang memiliki prinsip hidup itu masyarakat Buton menyebut budimani. Sebagai implikasi perilaku tersebut membentuk masyarakat yang memiliki ikatan sosial dalam berbagai bentuk, 
walaupun masyarakat Buton dikenal sebagai salah satu daerah multietnis.

Realita yang ada menunjukkan bahwa nilai sosial dapat muncul pada diri seseorang apabila merasakan pentingnya orang lain terhadap keberadaan dirinya. Pada aspek ini tersirat makna bahwa nilai sosial terbentuk oleh rasa saling membutuhkan dengan didasari oleh hati yang bersih. Pada konteks ini setiap manusia pada dasarnya mempunyai hati yang bersih yakni 'hati nurani' yang perlu dibiasakan. Nilai-nilai kearifan lokal perlu ditanamkan secara dini, baik yang diberikan oleh orang tua, anggota masyarakat, maupun guru melalui pendidikan karakter di sekolah.

Pandangan hidup masyarakat terhadap hubungan rmanusia dengan manusia didasarkan pada syariat Islam, sebagaimana tercakup dalam falsah Buton 'bhinci-bhinciki kuli'. Falsafah ini mengandung empat prinsip kehidupan masyarakat Buton, yaitu pomaa-maasika 'saling menyayangi', pomae-maeka 'saling menyegani (menakuti)', popia-piara 'saling memelihara', dan poangka-angkataka 'saling menghormati'. Dengan prinsip hidup ini, maka masyarakat Buton cenderung berusaha membantu orang, peduli sesama, mengikhlaskan, dan toleransi terhadap keberagaman.

\section{Relevansi Nilai-nilai Kearifan Lokal dengan Pilar Pendidikan Karakter}

Temuan analisis menyimpulkan bahwa kabanti pada dasarnya berisi ajaran tentang kehidupan yang ideal. Hal ini dimaksudkan agar masyarakat Buton memahami eksistensi dirinya baik sebagai pemerintah maupun sebagai masyarakat. Jika dirangkum nilai-nilai kearifan lokal pada ketiga kabanti, maka cakupan nilai meliputi: (a) ketakwaan, (b) budi pekerti, (c) toleran terhadap keberagaman, (d) tolong-menolong, (e) kasih sayang, (f) ikhlas/rela berkorban, (g) saling menghargai, (h) pantang menyerah, (i) kebersamaan, (j) kreatif dan inovatif, dan (k) bela negara.

Oleh karena itu nilai-nilai kearifan lokal masyarakat Buton pada kabanti sangat relevan dengan pilar pendidikan karakter yakni menanamkan nilai-nilai kehidupan. Nilai-nilai kearifan lokal dalam kabanti dapat diimplementasikan dalam pendidikan karakter, karena semua nilai-nilai luhur yang dianalisis mengandung nilai-nilai karakter. Karena pendidikan karakter menjadi target kurikulum, maka perlu kolaborasi antara nilai-nilai kearifan lokal dengan materi pendidikan karakter. Jadi, upaya guru adalah menggunakan momen budaya masyarakat untuk mempercepat pemahaman siswa, sehingga kemerosotan moral generasi muda yang mulai tampak saat ini dapat diminimalisir. Di samping itu, siswa mengenal nilai-nilai luhur masyarakat secara dini, sehingga 
diharapkan menjadi penangkal (filter) dari berbagai dampak pengaruh budaya asing. Dengan pemahaman dini, siswa diharapkan dapat memanfaatkan nilainilai kearifan lokal sebagai landasan untuk mengembangkan kemajuan ilmu dan teknologi yang inovatif dan kreatif sebagai bentuk local genius mereka.

Pendidikan karakter di Indonesia ditekankan pada sepuluh pilar, yaitu cinta kepada Allah, disiplin dan mandiri, jujur, hormat dan santun, kasih sayang, kerja sama, kerja keras/kreatif, kepemimpinan yang adil, rendah hati, dan bertoleransi terhadap keberagaman. Keseluruhan pilar tersebut sangat relevan dengan nilai-nilai kearifan lokal dalam kabanti masyarakat Buton.

Oleh karena itu, nilai-nilai kearifan lokal tersebut dapat dikolaborasikan dalam pengembangan pembelajaran pendidikan karakter di sekolah. Dengan kata lain, guru dapat menggunakan nilai-nilai kearifan lokal sebagai bahan pembelajaran dalam pendidikan karakter. Langkah ini dapat mempermudah penerimaan siswa, karena siswa dapat memperoleh melalui pengalaman dalam kehidupannya sehari-hari.

\section{Simpulan}

Berdasarkan pembahasan hasil dapat disimpulkan bahwa (1) Nilai-nilai kearifan lokal dalam kabanti pada aspek religius sangat kental dengan nilainilai keislaman. Masyarakat selalu menyadari eksistensi diri sebagai hamba Allah, dan selalu mengarah kepada sifat-sifat merendah, selalu bersyukur, dan bertawakal kepada Maha Pencipta. (2) Nilai-nilai kearifan lokal dalam kabanti pada aspek norma mencakup tiga pilar norma yaitu; norma hukum, norma sosial, dan norma adat-istiadat yang masing-masing norma memiliki peranan penting dalam tata kehidupan masyarakat, karena dapat menjadi pedoman bersikap dan berperilaku. Norma hukum menjadi acuan penerapan hukum, norma sosial menjadi acuan memberikan sanksi sosial terhadap pelanggaran susila, dan aspek norma adat-istiadat menjadi acuan penerapan sanksi terhadap pelanggaran adat masyarakat Buton. (3) Nilai-nilai kearifan lokal dalam kabanti pada aspek sosial mencakup akhlakul karimah yang dalam kabanti diberikan istilah budimani. Budimani mempunyai indikator yang merujuk pada falsafah 'bhinci-bhinciki kuli' yaitu pomaa-maasiaka, 'sesama manusia harus selalu saling menyayangi', pomae-maeka, 'sesama manusia harus selalu saling menghormati', popia-piara, 'sesama manusia harus selalu saling melindungi', dan poangkaangkataka, 'sesama manusia harus selalu saling memuliakan'. (4) Relevansi nilai-nilai kearifan lokal dalam kabanti dengan pendidikan karakter. Nilainilai kearifan lokal tersebut mencakup nilai ketakwaan, budi pekerti, toleran 
terhadap keberagaman, tolong-menolong, kasih sayang, rela berkorban, saling menghargai, kebersamaan, kerja keras, kreatif/inovatif, dan bela negara.

\section{Daftar Pustaka}

Adimahardja, Kusnaka. 2008. Dianamika Budaya Lokal. Bandung: Indra Prahasta dan Pusat Kajian LPPB.

Eco, Umberto. 1976. A Theory of Semiotics. Bloomington-London: Indiana University Press.

Endraswara, Suwardi. 2003. Metodologi Penelitian Sastra: Epistemologi, Model, Teori, dan Aplikasi. Yogyakarta: Universitas Negeri Yogyakarta.

Gunawan, Restu. 2003. Kearifan Lokal dalam Tradisi Lisan. Jakarta: Pusat Bahasa.

Glaser, B \& Strauss A. 1967. The Discovery of Grounded Theory. Chicago: Aldine.

Niampe, La. 2000. Kabanti Oni Wolio: Puisi Berbahasa Wolio. Jakarta: Pusat Pembinaan dan Pengembangan Bahasa.

Pradopo, Rachmat Djoko. 2000. Pengkajian Puisi: Analisis Strata Norma dan Analisis Struktural dan Semiotik. Yogyakarta: Gadjah Mada University Press.

Rahyono, F.X. 2009. Kearifan Budaya dalam Kata. Jakarta: Wadatama Widya Sastra.

Schoorl, JW. 1994. Power Ideology and Chang in State of Buton. Leiden: KITL

Supriyoko, Ki Ed. 2005. Pendidikan Multikultural dan Revitalisasi Hukum Adat: dalam Perspektif Sejarah. Jakarta: Karya Agung.

Sztompka, Piotr. 2008. The Sociology of Change. (Alih bahasa Alimandan). Jakarata: Prenada Media Groop.

Taalami, Laode. Dkk. 2010. Kearifan Lokal dalam Kebudayaan Suku Bangsa di Sulawesi Tenggara. Kendari: Kebudayaan dan Parawisata Sultra. 